Cellular Physiology
and Biochemistry and Biochemistry Published online: August 12, 2016

Accepted: July 20, 2016

This article is licensed under the Creative Commons Attribution-NonCommercial-NoDerivatives 4.0 International License (CC BY-NC-ND) (http://www.karger.com/Services/OpenAccessLicense). Usage and distribution for commercial purposes as well as any distribution of modified material requires written permission.

\title{
Stimulation of Eryptosis by Caspofungin
}

\author{
Thomas Peter Rosi Bissinger Florian Lang \\ Department of Cardiology, Vascular Medicine and Physiology, Eberhard-Karls-University of Tuebingen, \\ Tuebingen, Germany
}

\section{Key Words}

Phosphatidylserine $\cdot$ Caspofungin $•$ Cell volume $\cdot$ Eryptosis $•$ Hemolysis $•$ Casein kinase

\begin{abstract}
Background/Aims: The echinocandin antifungal agent caspofungin has been shown to trigger apoptosis of fungal cells. Beyond that, caspofungin is toxic for host mitochondria. Even though lacking mitochondria, erythrocytes may enter apoptosis-like suicidal erythrocyte death or eryptosis, characterized by cell shrinkage and cell membrane scrambling with phosphatidylserine translocation to the erythrocyte surface. Signaling involved in triggering of eryptosis include increase of cytosolic $\mathrm{Ca}^{2+}$ activity $\left(\left[\mathrm{Ca}^{2+}\right]_{\mathrm{i}}\right)$, oxidative stress, ceramide, caspase activation and/ or activation of p38 kinase, protein kinase $C$, and casein kinase. The present study explored, whether caspofungin induces eryptosis and, if so, to shed some light on the cellular mechanisms involved. Methods: Flow cytometry was employed to determine phosphatidylserine exposure at the cell surface from annexin-V-binding, cell volume from forward scatter, $\left[\mathrm{Ca}^{2+}\right]_{\text {i }}$ from Fluo3-fluorescence, ROS formation from DCFDA dependent fluorescence, and ceramide abundance utilizing specific antibodies. Hemolysis was quantified from hemoglobin concentration in the supernatant. Results: A 48 hours exposure of human erythrocytes to caspofungin ( $\geq 30 \mu \mathrm{g} / \mathrm{ml}$ ) significantly increased the percentage of annexin$\mathrm{V}$-binding cells, significantly decreased forward scatter, significantly enhanced hemolysis, but did not significantly increase Fluo3-fluorescence, DCFDA fluorescence or ceramide abundance. The effect of caspofungin on annexin-V-binding was not significantly blunted by removal of extracellular $\mathrm{Ca}^{2+}$, by inhibition of caspases with pancaspase inhibitor zVAD $(10 \mu \mathrm{M})$, or by addition of the antioxidant $\mathrm{N}$-acetyl-cysteine $(1 \mathrm{mM})$, p38 kinase inhibitor SB203580 (2 $\mu \mathrm{M})$ or protein kinase $C$ inhibitor staurosporine $(1 \mu \mathrm{M})$. The effect of caspofungin on annexin-Vbinding was, however, significantly blunted in the presence of casein kinase inhibitor D4476 $(10 \mu \mathrm{M})$. Conclusions: Caspofungin triggers cell shrinkage and phospholipid scrambling of the erythrocyte cell membrane, an effect possibly involving activation of casein kinase.
\end{abstract}

\section{Introduction}

Caspofungin, an echinocandin antifungal agent [1], is utilized for the treatment of diverse fungal infections [1-27]. Its antifungal action is accomplished by inhibition of $\beta-1,3-$ d-glucan polymer synthesis [1]. Moreover, caspofungin has been shown to trigger apoptosis 


\section{Cellular Physiology Cell Physiol Biochem 2016;39:939-949 \begin{tabular}{l|l|l|} 
and BOI: 10.1159/000447802 & $\begin{array}{l}\text { C) 2016 The Author(s). Published by S. Karger AG, Basel } \\
\text { www.karger.com/cpb }\end{array}$
\end{tabular} \\ Peter/Bissinger/Lang: Caspofungin-Induced Eryptosis}

of Candida albicans [28]. The substance may be toxic as well for host cells and for host mitochondria [29].

Erythrocytes lack mitochondria but could nevertheless enter apoptosis-like suicidal death or eryptosis [30], which is characterized by cell shrinkage [31] and cell membrane scrambling with phosphatidylserine translocation to the cell surface [30]. A wide variety of apoptosis inducing substances similarly trigger eryptosis [30, 32-75]. Triggering of eryptosis may involve increase of cytosolic $\mathrm{Ca}^{2+}$ activity $\left(\left[\mathrm{Ca}^{2+}\right]_{\mathrm{i}}\right)[30]$, ceramide [76], oxidative stress [30], energy depletion [30], activated caspases [30, 77, 78], and stimulation of casein kinase $1 \alpha$, Janus-activated kinase JAK3, protein kinase C, and/or p38 kinase [30]. Eryptosis is inhibited following activation of AMP activated kinase AMPK, cGMP-dependent protein kinase, and sorafenib/sunitinib sensitive kinases [30].

The present study explored, whether caspofungin is capable to trigger eryptosis. Erythrocytes from healthy volunteers were treated with caspofungin and phosphatidylserine surface abundance, cell volume, $\left[\mathrm{Ca}^{2+}\right]_{\mathrm{i}}$, ROS formation, and ceramide abundance determined by flow cytometry.

\section{Materials and Methods}

\section{Erythrocytes, solutions and chemicals}

Fresh Li-Heparin-anticoagulated blood samples were kindly provided by the blood bank of the University of Tübingen. The study is approved by the ethics committee of the University of Tübingen (184/2003 V). The blood was centrifuged at $120 \mathrm{xg}$ for $20 \mathrm{~min}$ at $21^{\circ} \mathrm{C}$ and the platelets and leukocytes-containing supernatant was disposed. Erythrocytes were incubated in vitro at a hematocrit of $0.4 \%$ in Ringer solution containing (in mM) $125 \mathrm{NaCl}, 5 \mathrm{KCl}, 1 \mathrm{MgSO}_{4}, 32 \mathrm{~N}$-2-hydroxyethylpiperazine-N-2-ethanesulfonic acid (HEPES; pH 7.4), 5 glucose, $1 \mathrm{CaCl}_{2}$, at $37^{\circ} \mathrm{C}$ for 48 hours. Where indicated, erythrocytes were exposed for 48 hours to caspofungin (MedChem Express, Princeton, USA). In order to explore, whether eryptosis required entry of extracellular $\mathrm{Ca}^{2+}$, experiments were performed in the nominal absence of extracellular $\mathrm{Ca}^{2+}$ and addition of $1 \mathrm{mM}$ EDTA (Sigma Aldrich, Hamburg, Germany). To test for an involvement of kinases, erythrocytes were exposed for 48 hours to a combination of caspofungin and casein kinase inhibitor D4476 (Sigma Aldrich, Hamburg, Germany), p38 kinase inhibitor SB203580 (Tocris bioscience, Bristol, UK) or protein kinase C inhibitor staurosporine (Sigma Aldrich, Hamburg, Germany). The involvement of oxidative stress was tested by addition of the antioxidant N-acetylcysteine (Sigma Aldrich, Hamburg, Germany), the involvement of caspases by addition of the pancaspase inhibitor zVAD (Sigma Aldrich, Hamburg, Germany).

\section{Annexin-V-binding and forward scatter}

After incubation under the respective experimental condition, a $150 \mu \mathrm{l}$ cell suspension was washed in Ringer solution containing $5 \mathrm{mM} \mathrm{CaCl}_{2}$ and then stained with Annexin-V-FITC (1:200 dilution; ImmunoTools, Friesoythe, Germany) in this solution at $37^{\circ} \mathrm{C}$ for $15 \mathrm{~min}$ under protection from light. The annexin-Vabundance at the erythrocyte surface was subsequently determined on a FACS Calibur (BD, Heidelberg, Germany). Annexin-V-binding was measured with an excitation wavelength of $488 \mathrm{~nm}$ and an emission wavelength of $530 \mathrm{~nm}$. A marker (M1) was placed to set an arbitrary threshold between annexin-V-binding cells and control cells. The same threshold was used for untreated and caspofungin treated erythrocytes. Alterations of cell volume were estimated by determination of forward scatter (FSC). The threshold of forward scatter was set at the default value of " 52 ".

\section{Intracellular $\mathrm{Ca}^{2+}$}

After incubation, erythrocytes were washed in Ringer solution and then loaded with Fluo-3/AM (Biotium, Hayward, USA) in Ringer solution containing $5 \mathrm{mM} \mathrm{CaCl}_{2}$ and $5 \mu \mathrm{M}$ Fluo-3/AM. The cells were incubated at $37^{\circ} \mathrm{C}$ for $30 \mathrm{~min}$ and washed once in Ringer solution containing $5 \mathrm{mM} \mathrm{CaCl} \mathrm{Cl}_{2}$ The Fluo-3/ AM-loaded erythrocytes were resuspended in $200 \mu$ l Ringer solution. Then, $\mathrm{Ca}^{2+}$-dependent fluorescence intensity was measured in FL-1 channel with an excitation wavelength of $488 \mathrm{~nm}$ and an emission wavelength of $530 \mathrm{~nm}$ on a FACS Calibur. Afterwards, the geomean of the $\mathrm{Ca}^{2+}$ dependent fluorescence was determined. 


\section{Cellular Physiology Cell Physiol Biochem 2016;39:939-949 and Biochemistry \begin{tabular}{l|l} 
DOI: 10.1159/000447802 & (c) 2016 The Author(s). Published by S. Karger AG, Basel \\
www.karger.com/cpb
\end{tabular} \\ Peter/Bissinger/Lang: Caspofungin-Induced Eryptosis}

Reactive oxygen species (ROS)

The abundance of ROS was determined utilizing 2',7'-dichlorodihydrofluorescein diacetate (DCFDA). After incubation, a $150 \mu \mathrm{l}$ suspension of erythrocytes was washed in Ringer solution and stained with DCFDA (Sigma, Schnelldorf, Germany) in Ringer solution containing DCFDA at a final concentration of $10 \mu$ M. Erythrocytes were incubated at $37^{\circ} \mathrm{C}$ for $30 \mathrm{~min}$ in the dark and washed two times in Ringer solution. The DCFDA-loaded erythrocytes were resuspended in $200 \mu$ l Ringer solution and ROS-dependent fluorescence intensity was measured in FL-1 channel at an excitation wavelength of $488 \mathrm{~nm}$ and an emission wavelength of $530 \mathrm{~nm}$ on a FACS Calibur (BD). Subsequently, the geomean of the DCFDA dependent fluorescence was determined.

\section{Ceramide abundance}

To determine the ceramide abundance at the erythrocyte surface, a monoclonal antibody was used. After incubation, cells were stained for $1 \mathrm{~h}$ at $37^{\circ} \mathrm{C}$ with $1 \mu \mathrm{g} / \mathrm{ml}$ anti-ceramide antibody (clone MID 15B4; Alexis, Grünberg, Germany) in phosphate-buffered saline (PBS) containing $0.1 \%$ bovine serum albumin (BSA) at a dilution of 1:10. After two washing steps with PBS-BSA, cells were stained for 30 min with polyclonal fluorescein-isothiocyanate (FITC)-conjugated goat anti-mouse IgG/IgM (concentration $0.5 \mathrm{mg}$ / $\mathrm{ml}$ ) specific antibody (BD Pharmingen, Hamburg, Germany) diluted 1:50 in PBS-BSA. Unbound secondary antibody was removed by repeated washing with PBS-BSA. Samples were then analyzed by flow cytometric analysis in FL-1 channel at an excitation wavelength of $488 \mathrm{~nm}$ and an emission wavelength of $530 \mathrm{~nm}$. Finally, the geomean of the ceramide dependent fluorescence was determined.

\section{Hemolysis}

Following incubation, the erythrocyte suspension was centrifuged for $3 \mathrm{~min}$ at $1600 \mathrm{rpm}, 4^{\circ} \mathrm{C}$, and the supernatants were harvested. As a measure of hemolysis, the hemoglobin ( $\mathrm{Hb}$ ) concentration of the supernatants was determined photometrically at $405 \mathrm{~nm}$. The absorption of the supernatant of erythrocytes lysed in distilled water was defined as $100 \%$ hemolysis.

\section{Statistics}

Data are expressed as arithmetic means \pm SEM. As indicated in the figure legends, statistical analysis was made using ANOVA with Tukey's test as post-test and $t$ test as appropriate. $\mathrm{n}$ denotes the number of different erythrocyte specimens studied. Since different erythrocyte specimens used in distinct experiments are differently susceptible to triggers of eryptosis, the same erythrocyte specimens have been used for control and experimental conditions.

\section{Results}

The present study explored whether caspofungin influences eryptosis, the suicidal erythrocyte death characterized by cell shrinkage and phospholipid scrambling of the cell membrane with phosphatidylserine translocation to the cell surface.

Erythrocyte volume was estimated from forward scatter, which was determined utilizing flow cytometry. Prior to measurements, the erythrocytes were incubated for 48 hours in Ringer solution without or with caspofungin $(30-60 \mu \mathrm{g} / \mathrm{ml})$. As illustrated in Fig. $1 \mathrm{~A}, \mathrm{~B}$, caspofungin significantly decreased erythrocyte forward scatter at each caspofungin concentration tested. Moreover, caspofungin $(\geq 45 \mu \mathrm{g} / \mathrm{ml})$ significantly increased the percentage of shrunken erythrocytes (Fig, 1C) and significantly decreased the percentage of swollen erythrocytes (Fig. 1D) at each caspofungin concentration tested.

Phosphatidylserine exposing erythrocytes were identified utilizing annexin-V-binding, as determined by flow cytometry. Prior to measurements, the erythrocytes were again incubated for 48 hours in Ringer solution without or with caspofungin $(30-60 \mu \mathrm{g} / \mathrm{ml})$. As shown in Fig. 2A,B, a 48 hours exposure to caspofungin increased the percentage of phosphatidylserine exposing erythrocytes at each caspofungin concentration tested. 


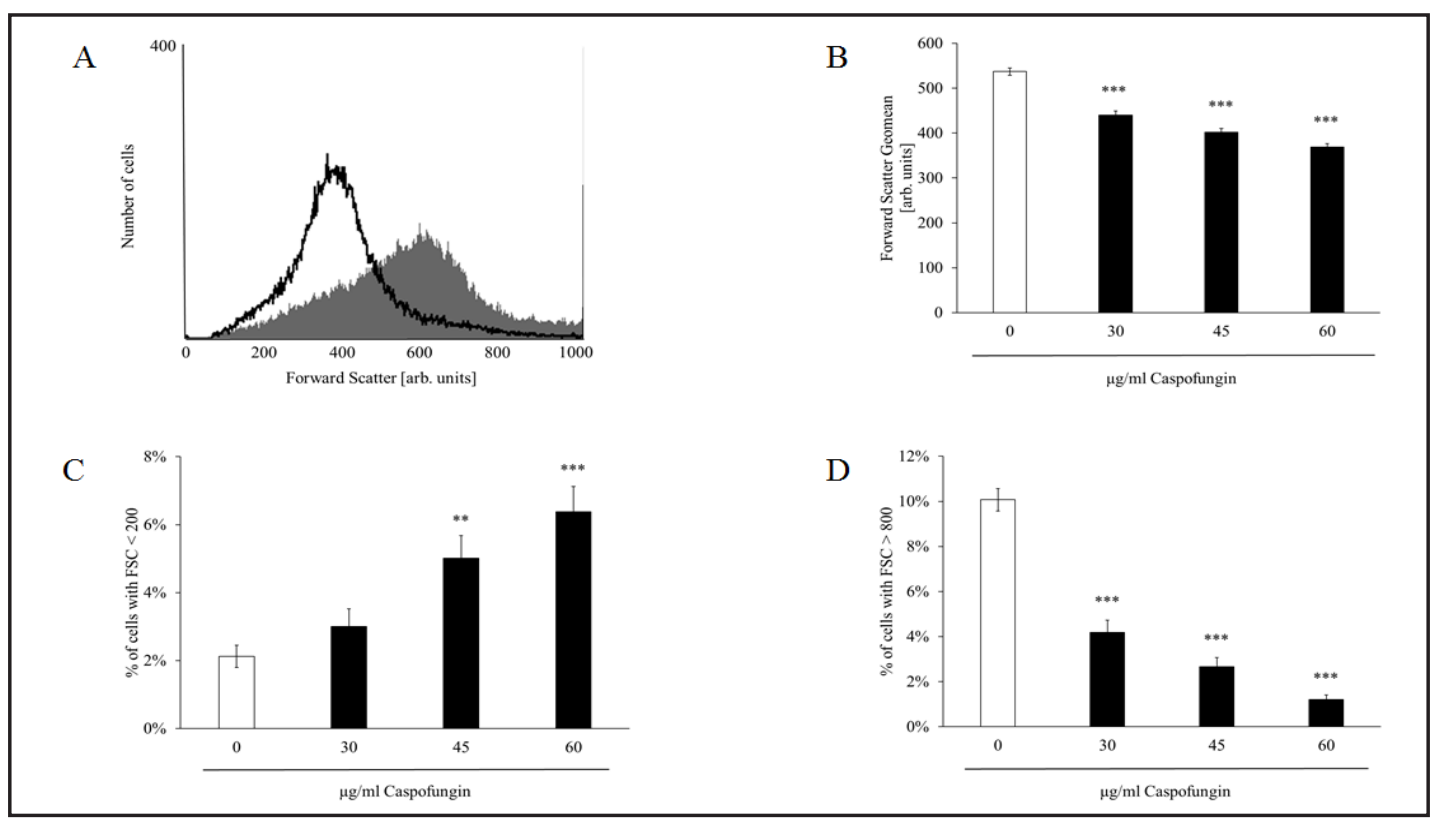

Fig. 1. Effect of caspofungin on erythrocyte forward scatter. A. Original histograms of forward scatter of erythrocytes following exposure for 48 hours to Ringer solution without (grey area) and with (black line) presence of $60 \mu \mathrm{g} / \mathrm{ml}$ caspofungin. B. Arithmetic means \pm SEM $(\mathrm{n}=21)$ of the erythrocyte forward scatter (FSC) following incubation for 48 hours to Ringer solution without (white bar) or with (black bars) caspofungin (30 - $60 \mu \mathrm{g} / \mathrm{ml})$. C,D. Percentage of erythrocytes with (C) FSC $<200$ or (D) FSC $>800$ following incubation for 48 hours to Ringer solution without (white bar) or with (black bars) caspofungin (30 - 60 $\mu \mathrm{g} / \mathrm{ml}){ }^{* *}(\mathrm{p}<0.01),{ }^{* *}(\mathrm{p}<0.001)$ indicate significant difference from the absence of caspofungin (ANOVA).

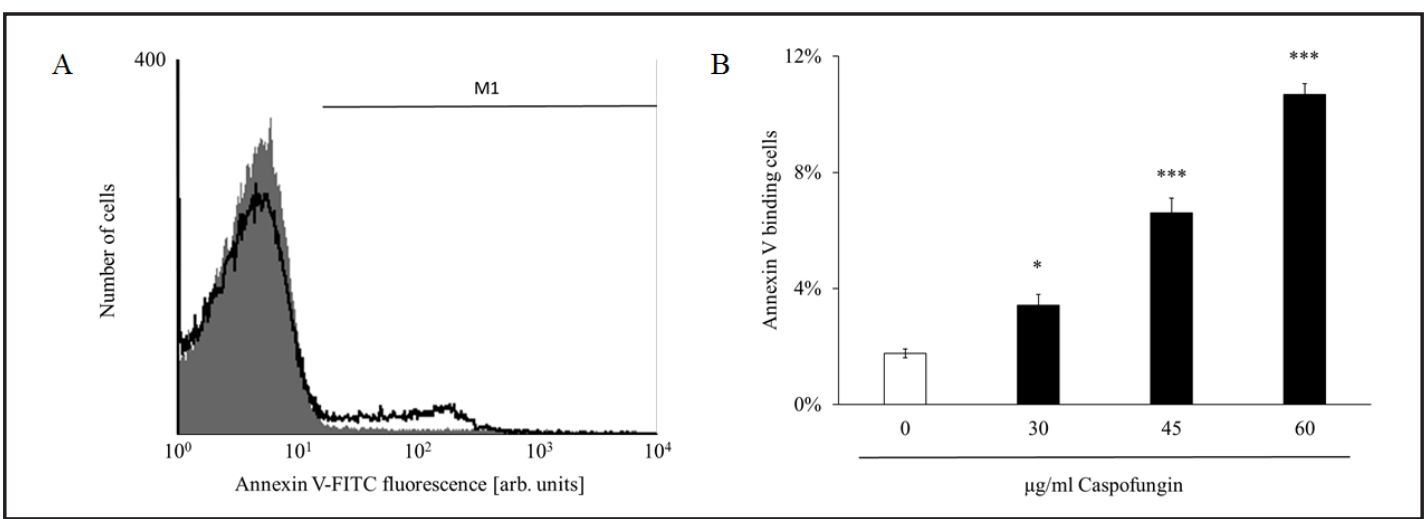

Fig. 2. Effect of caspofungin on phosphatidylserine exposure. A. Original histograms of annexin-V-binding of erythrocytes following exposure for 48 hours to Ringer solution without (grey area) and with (black line) presence of $60 \mu \mathrm{g} / \mathrm{ml}$ caspofungin. B. Arithmetic means \pm SEM $(\mathrm{n}=21)$ of erythrocyte annexin-V-binding following incubation for 48 hours to Ringer solution without (white bar) or with (black bars) caspofungin $(30-60 \mu \mathrm{g} / \mathrm{ml}) .{ }^{*}(\mathrm{p}<0.05),{ }^{* * *}(\mathrm{p}<0.001)$ indicate significant difference from the absence of caspofungin (ANOVA).

Hemoglobin concentration in the supernatant was taken as a measure of hemolysis. Prior to measurements, the erythrocytes were again incubated for 48 hours in Ringer solution without or with caspofungin $(30-60 \mu \mathrm{g} / \mathrm{ml})$. As shown in Fig. 3, a 48 hours exposure to caspofungin increased the percentage of hemolytic erythrocytes at each caspofungin concentration tested.

Fluo3 fluorescence was taken as a measure of cytosolic $\mathrm{Ca}^{2+}$ activity $\left(\left[\mathrm{Ca}^{2+}\right]_{\mathrm{i}}\right)$. As a result, following a 48 hours incubation, the Fluo3 fluorescence was similar in the absence of caspofungin (24.77 \pm 1.02 a.u., $\mathrm{n}=21)$ and in the presence of $30 \mu \mathrm{g} / \mathrm{ml}$ caspofungin 


\section{Cellular Physiology Cell Physiol Biochem 2016;39:939-949 \begin{tabular}{ll|l} 
DOI: 10.1159/000447802 & a 2016 The Author(s). Published by S. Karger AG, Basel \\
wwww.karger.com/cpb
\end{tabular} \\ Peter/Bissinger/Lang: Caspofungin-Induced Eryptosis}

Fig. 3. Effect of caspofungin on hemolysis. Arithmetic means \pm SEM $(n=21)$ of the percentage of hemolytic erythrocytes following incubation for 48 hours to Ringer solution without (white bar) or with (black bars) caspofungin $(30-60 \mu \mathrm{g} / \mathrm{ml}) . * * *(\mathrm{p}<0.001)$ indicates significant difference from the absence of caspofungin (ANOVA).
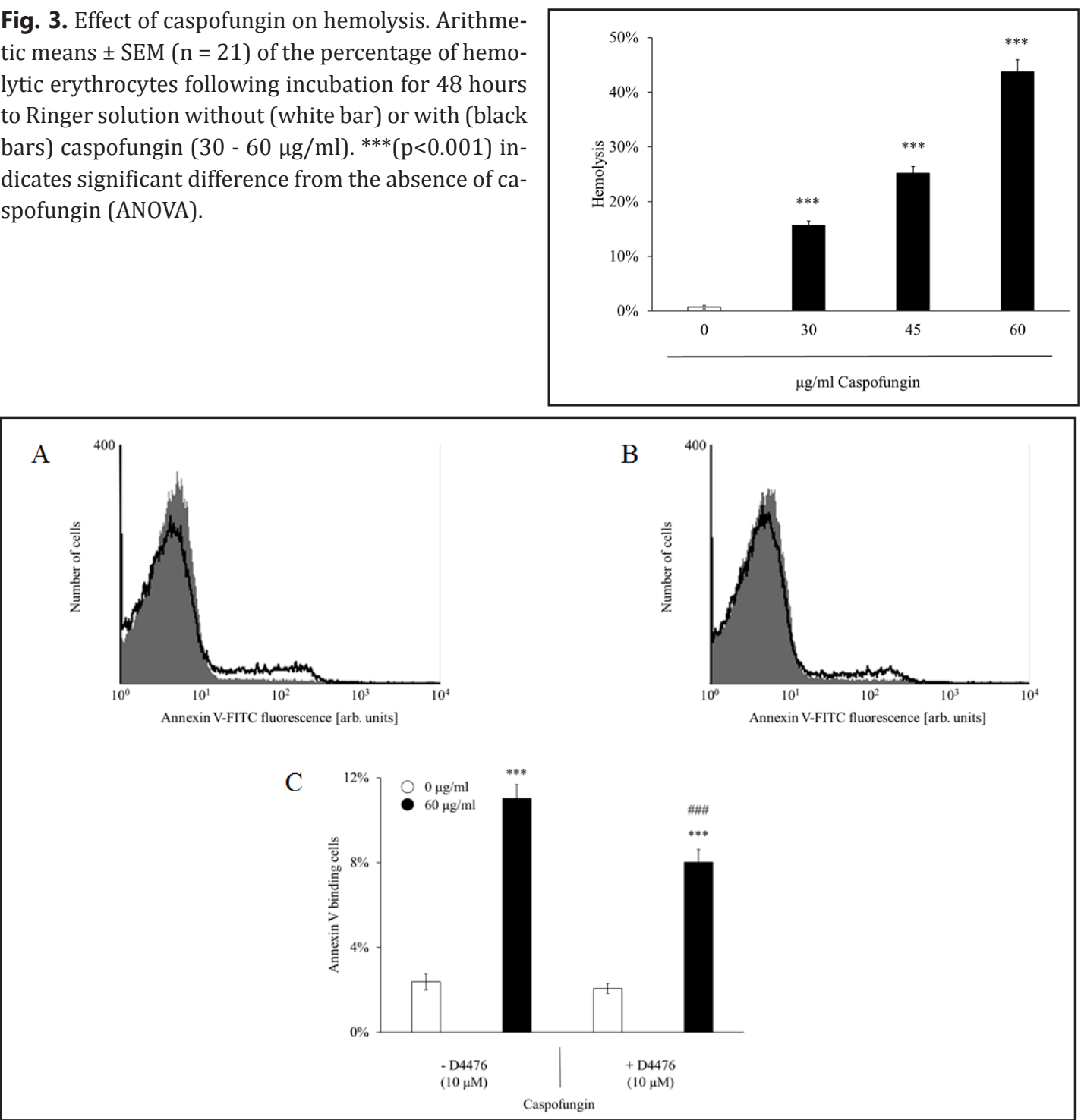

Fig. 4. D4476 sensitivity of caspofungin-induced phosphatidylserine exposure. A,B. Original histograms of annexin-V-binding of erythrocytes following exposure for 48 hours to Ringer solution without (grey area) and with (black line) caspofungin $(60 \mu \mathrm{g} / \mathrm{ml})$ in the absence (A) and presence (B) of casein kinase inhibitor D4476 $(10 \mu \mathrm{M})$. C. Arithmetic means \pm SEM $(n=16)$ of annexin-V-binding of erythrocytes after a 48 hours treatment with Ringer solution without (white bars) or with (black bars) caspofungin ( $60 \mu \mathrm{g} / \mathrm{ml})$ in the absence (left bars, -D4476) and presence (right bars, +D4476) of casein kinase inhibitor D4476 (10 $\mu \mathrm{M})$. $* * *(p<0.001)$ indicates significant difference from the absence of caspofungin, $\# \# \#(p<0.001)$ indicates significant difference from the absence of D4476 (ANOVA).

(23.87 \pm 1.05 a.u., $\mathrm{n}=21$ ), of $45 \mu \mathrm{g} / \mathrm{ml}$ caspofungin $(24.61 \pm 1.04$ a.u., $\mathrm{n}=21$ ) and of 60 $\mu \mathrm{g} / \mathrm{ml}$ caspofungin $(27.20 \pm 1.23$ a.u., $\mathrm{n}=21)$. Further experiments were performed in order to elucidate whether the caspofungin-induced translocation of phosphatidylserine required entry of extracellular $\mathrm{Ca}^{2+}$. To this end, erythrocytes were incubated for 48 hours in the absence or presence of $60 \mu \mathrm{g} / \mathrm{ml}$ caspofungin in the presence or nominal absence of extracellular $\mathrm{Ca}^{2+}$. As a result, exposure to caspofungin significantly $(\mathrm{p}<0.001)$ increased the percentage of annexin-V-binding cells to a similar extent in the presence (from $1.36 \pm 0.13$ $\%$ to $9.61 \pm 0.63 \%, \mathrm{n}=16$ ) and in the absence (from $1.19 \pm 0.08 \%$ to $9.37 \pm 0.57 \%, \mathrm{n}=16$ ) of extracellular $\mathrm{Ca}^{2+}$. Thus, the caspofungin-induced cell membrane scrambling was in large part triggered by mechanisms other than entry of extracellular $\mathrm{Ca}^{2+}$. 


\section{Cellular Physiology Cell Physiol Biochem 2016;39:939-949 \begin{tabular}{l|l|l|}
\hline DOI: 10.1159/000447802 & $\begin{array}{l}\text { C) 2016 The Author(s). Published by S. Karger AG, Basel } \\
\text { www.karger.com/cpb }\end{array}$
\end{tabular} \\ Peter/Bissinger/Lang: Caspofungin-Induced Eryptosis}

Eryptosis is further stimulated by oxidative stress. Reactive oxygen species (ROS) was thus quantified utilizing $2^{\prime}, 7^{\prime}$-dichlorodihydrofluorescein diacetate (DCFDA). As a result, the DCFDA fluorescence was even significantly $(\mathrm{p}<0.001)$ lower following exposure to $45 \mu \mathrm{g} /$ $\mathrm{ml}$ caspofungin (10.04 \pm 0.30 a.u., $\mathrm{n}=8)$ than in the absence of caspofungin (15.41 \pm 0.26 a.u., $n=8$ ). Thus, caspofungin did not appreciably induce oxidative stress. To further test for an impact of oxidative stress, erythrocytes were incubated for 48 hours in the absence or presence of $60 \mu \mathrm{g} / \mathrm{ml}$ caspofungin in the presence or nominal absence of the antioxidant $\mathrm{N}$-acetyl-cysteine $(1 \mathrm{mM})$. As a result, exposure to caspofungin significantly $(\mathrm{p}<0.001)$ increased the percentage of annexin-V-binding cells to a similar extent in the absence (from $1.50 \pm 0.19 \%$ to $12.27 \pm 0.84 \%, \mathrm{n}=8$ ) and in the presence (from $2.08 \pm 0.47 \%$ to $12.84 \pm$ $0.86 \%, \mathrm{n}=8$ ) of $\mathrm{N}$-acetyl-cysteine. Thus, caspofungin-induced cell membrane scrambling was not dependent on oxidative stress.

A further stimulator of eryptosis is ceramide. Ceramide abundance at the erythrocyte surface was thus quantified utilizing specific antibodies. As a result, the ceramide abundance was similar following exposure to $45 \mu \mathrm{g} / \mathrm{ml}$ caspofungin (13.64 \pm 0.45 a.u., $\mathrm{n}=5)$ and in the absence of caspofungin (15.42 \pm 0.22 a.u., $n=5$ ). Thus, caspofungin did not appreciably induce ceramide abundance.

To explore, whether the effect of caspofungin on phosphatidylserine translocation required caspase activation, the influence of caspofungin on annexin-V-binding was tested in the presence or absence of pancaspase inhibitor zVAD. As a result, exposure to caspofungin significantly $(\mathrm{p}<0.001)$ increased the percentage of annexin-V-binding cells to a similar extent in the absence (from $1.36 \pm 0.10 \%$ to $12.18 \pm 0.81 \%, \mathrm{n}=8$ ) and in the presence (from $1.59 \pm 0.11 \%$ to $11.32 \pm 0.78 \%, \mathrm{n}=8)$ of zVAD $(10 \mu \mathrm{M})$. Thus, the caspofungin-induced cell membrane scrambling did not require caspase activity.

To explore, whether the effects of caspofungin involved kinase activity, the influence of caspofungin on annexin-V-binding was tested in the presence or absence of kinase inhibitors. As a result, exposure to caspofungin significantly $(\mathrm{p}<0.001)$ increased the percentage of annexin-V-binding cells to a similar extent in the absence (from $2.18 \pm 0.54 \%$ to $11.04 \pm$ $0.90 \%, \mathrm{n}=8$ ) and in the presence (from $2.25 \pm 0.53 \%$ to $10.32 \pm 0.72 \%, \mathrm{n}=8$ ) of p38 kinase inhibitor SB203580 $(2 \mu \mathrm{M})$. Thus, the caspofungin-induced cell membrane scrambling was not dependent on $p 38$ kinase activity. Exposure to caspofungin further significantly $(p<0.001)$ increased the percentage of annexin-V-binding cells even to a significantly $(p<0.05)$ higher extent in the presence (from $1.61 \pm 0.16 \%$ to $15.90 \pm 0.65 \%, \mathrm{n}=16$ ) than in the absence (from $1.60 \pm 0.13 \%$ to $11.12 \pm 0.69 \%, \mathrm{n}=16$ ) of protein kinase $\mathrm{C}$ inhibitor staurosporine $(1 \mu \mathrm{M})$. Thus, the caspofungin-induced cell membrane scrambling was not dependent on protein kinase $\mathrm{C}$ activity.

As illustrated in Fig. 4A-C, the caspofungin $(60 \mu \mathrm{g} / \mathrm{ml})$ increased phosphatidylserine exposure was significantly blunted in the presence of casein kinase inhibitor D4476. However, even in the presence of D4476, caspofungin significantly increased phosphatidylserine exposure, an observation pointing to the involvement of additional mechanisms.

\section{Discussion}

The present study reveals a novel effect of caspofungin, i.e. the stimulation of eryptosis, the suicidal erythrocyte death. Treatment of human erythrocytes to caspofungin is followed by cell shrinkage and cell membrane scrambling with phosphatidylserine translocation to the erythrocyte surface. The concentration of caspofungin required for this effect is well in the range of caspofungin concentrations encountered in vivo [79]. It must be kept in mind that the susceptibility to stimulators of eryptosis may be enhanced in several clinical conditions, such as dehydration [80], hyperphosphatemia [81], chronic kidney disease (CKD) [82-85], hemolytic-uremic syndrome [86], diabetes [87], hepatic failure [88], malignancy [30], sepsis [89], sickle-cell disease [30], beta-thalassemia [30], Hb-C and G6PD-deficiency [30], as well as Wilsons disease [90]. 


\section{Cellular Physiology Cell Physiol Biochem 2016;39:939-949 \begin{tabular}{ll|l} 
DOI: 10.1159/000447802 & $\begin{array}{l}\text { O 2016 The Author(s). Published by S. Karger AG, Basel } \\
\text { www.karger.com/cpb }\end{array}$ \\
\cline { 2 - 3 }
\end{tabular} \\ Peter/Bissinger/Lang: Caspofungin-Induced Eryptosis}

The effect of caspofungin on cell membrane scrambling was not paralleled by increase of cytosolic $\mathrm{Ca}^{2+}$ activity and not sensitive to $\mathrm{Ca}^{2+}$ removal from the extracellular space. Moreover, caspofungin triggered phosphatidylserine translocation to the erythrocyte surface without enhancing the ceramide abundance. Caspofungin triggered eryptosis without inducing oxidative stress and the effect of caspofungin on cell membrane scrambling was not significantly modified by addition of the antioxidant $\mathrm{N}$-acetyl-cysteine. The effect of caspofungin did further not require caspase activation, the activity of p38 kinase or of staurosporine sensitive kinases such as protein kinase $\mathrm{C}$. The caspofungin induced cell membrane scrambling was thus independent from increase of cytosolic $\mathrm{Ca}^{2+}$ activity, oxidative stress, ceramide formation or activity of p38 kinase and staurosporine sensitive kinases, all major triggers of eryptosis [30]. Instead, the effect of caspofungin on cell membrane scrambling was blunted in the presence of casein kinase inhibitor D4476. Thus, the effect of caspofungin on cell membrane scrambling could involve casein kinase activation. However, effects of D4476 other than casein kinase inhibition cannot be ruled out. Moreover, even in the presence of D4476, caspofungin significantly enhanced phosphatidylserine translocation pointing to the involvement of further mechanisms.

Besides its effect on eryptosis, caspofungin triggered hemolysis. The physiological function of eryptosis is actually the clearance of defective erythrocytes from circulating blood prior to hemolysis [30]. If defective erythrocytes fail to enter timely eryptosis, hemolysis leads to release of hemoglobin, which passes the renal glomerular filter, precipitates in the acidic lumen of renal tubules, occludes nephrons and may thus cause renal failure [91].

The clearance of phosphatidylserine exposing erythrocytes may, on the other hand, lead to anemia if the loss of erythrocytes outcasts the formation of new erythrocytes by erythropoiesis [30]. Adherance of phosphatidylserine exposing erythrocytes to the vascular wall [92, 93] may further stimulate blood clotting and trigger thrombosis [94-96], thus compromising microcirculation [76, 94, 97-100].

\section{Conclusion}

Caspofungin triggers eryptosis with cell shrinkage and cell membrane scrambling, an effect apparently independent from $\mathrm{Ca}^{2+}$ entry, oxidative stress, ceramide, caspases, p38 kinase, and protein kinase $\mathrm{C}$ but presumably involving activation of casein kinase.

\section{Acknowledgements}

The authors acknowledge the meticulous preparation of the manuscript by Tanja Loch. The study was supported by the Deutsche Forschungsgemeinschaft and Open Access Publishing Fund of Tuebingen University.

\section{Disclosure Statement}

The authors have declared that no competing interests exist.

\section{References}

1 Song JC, Stevens DA: Caspofungin: Pharmacodynamics, pharmacokinetics, clinical uses and treatment outcomes. Crit Rev Microbiol 2015;10.3109/1040841X.2015.10682711-34.

2 Bhattacharyya A, Krishnan S, Saha V, Goel G, Bhattacharya S, Hmar L: Microbiology, infection control and infection related outcome in pediatric patients in an oncology center in Eastern India: Experience from Tata Medical Center, Kolkata. Indian J Cancer 2014;51:415-417.

3 Cornely OA, Meems L, Herbrecht R, Viscoli C, van Amsterdam RG, Ruhnke M: Randomised, multicentre trial of micafungin vs. an institutional standard regimen for salvage treatment of invasive aspergillosis. Mycoses 2015;58:58-64.

4 Cortegiani A, Russotto V, Maggiore A, Attanasio M, Naro AR, Raineri SM, Giarratano A: Antifungal agents for preventing fungal infections in non-neutropenic critically ill patients. Cochrane Database Syst Rev 2016;1:CD004920. 


\section{Cellular Physiology Cell Physiol Biochem 2016;39:939-949 and Biochemistry Published online: August 12, $2016 \quad$\begin{tabular}{l|l} 
DOI: 10.1159/000447802 2016 The Author(s). Published by S. Karger AG, Basel \\
www.karger.com/cpb
\end{tabular} \\ Peter/Bissinger/Lang: Caspofungin-Induced Eryptosis}

5 Esteves F, Medrano FJ, de Armas Y, Wissmann G, Calderon EJ, Matos O: Pneumocystis and Pneumocystosis: first meeting of experts from Latin-American and Portuguese-speaking countries - a mini-review. Expert Rev Anti Infect Ther 2014;12:545-548.

6 Jeurissen S, Vogelaers D, Sermijn E, Van Dycke K, Geerts A, Van Vlierberghe H, Colle I: Invasive aspergillosis in patients with cirrhosis, a case report and review of the last 10 years. Acta Clin Belg 2013;68:368-375.

7 Koulenti D, Garnacho-Montero J, Blot S: Approach to invasive pulmonary aspergillosis in critically ill patients. Curr Opin Infect Dis 2014;27:174-183.

8 Liss B, Vehreschild JJ, Bangard C, Maintz D, Frank K, Gronke S, Michels G, Hamprecht A, Wisplinghoff H, Markiefka B, Hekmat K, Vehreschild MJ, Cornely OA: Our 2015 approach to invasive pulmonary aspergillosis. Mycoses 2015;58:375-382.

9 Micallef C, Aliyu SH, Santos R, Brown NM, Rosembert D, Enoch DA: Introduction of an antifungal stewardship programme targeting high-cost antifungals at a tertiary hospital in Cambridge, England. J Antimicrob Chemother 2015;70:1908-1911.

10 Muilwijk EW, Lempers VJ, Burger DM, Warris A, Pickkers P, Aarnoutse RE, Bruggemann RJ: Impact of special patient populations on the pharmacokinetics of echinocandins. Expert Rev Anti Infect Ther 2015;13:799-815.

11 Neoh CF, Daniell M, Chen SC, Stewart K, Kong DC: Clinical utility of caspofungin eye drops in fungal keratitis. Int J Antimicrob Agents 2014;44:96-104.

12 Omrani AS, Makkawy EA, Baig K, Baredhwan AA, Almuthree SA, Elkhizzi NA, Albarrak AM: Ten-year review of invasive Candida infections in a tertiary care center in Saudi Arabia. Saudi Med J 2014;35:821-826.

13 Patel A, Bishburg E, Nagarakanti S: Mucormycosis in an HIV-infected renal transplant patient: A case report and review of the literature. Am J Case Rep 2014;15:74-78.

14 Perlin DS: Mechanisms of echinocandin antifungal drug resistance. Ann N Y Acad Sci 2015;1354:1-11.

15 Popiel KY, Wong P, Lee MJ, Langelier M, Sheppard DC, Vinh DC: Invasive Saccharomyces cerevisiae in a liver transplant patient: case report and review of infection in transplant recipients. Transpl Infect Dis 2015;17:435-441.

16 Rodriguez-Gutierrez G, Carrillo-Casas EM, Arenas R, Garcia-Mendez JO, Toussaint S, Moreno-Morales ME, Schcolnik-Cabrera AA, Xicohtencatl-Cortes J, Hernandez-Castro R: Mucormycosis in a Non-Hodgkin Lymphoma Patient Caused by Syncephalastrum racemosum: Case Report and Review of Literature. Mycopathologia 2015;180:89-93.

17 Safdar A, Rodriguez G, Zuniga J, Al Akhrass F, Pande A: High-dose caspofungin as a component of combination antifungal therapy in 91 patients with neoplastic diseases and hematopoietic stem cell transplantation: a critical review of short-term and long-term adverse events. J Pharm Pract 2015;28:175182.

18 Sheybani F, Naderi HR, Sarvghad M, Ghabouli M, Arian M: How should we manage a patient with invasive mucoromycosis who develops life-threatening reaction to amphotericin B? Report of two cases and literature review. Med Mycol Case Rep 2015;8:29-31.

19 Shields RK, Nguyen MH, Clancy CJ: Clinical perspectives on echinocandin resistance among Candida species. Curr Opin Infect Dis 2015;28:514-522.

20 Tacke D, Koehler P, Cornely OA: Fungal endocarditis. Curr Opin Infect Dis 2013;26:501-507.

21 Tu GW, Ju MJ, Xu M, Rong RM, He YZ, Xue ZG, Zhu TY, Luo Z: Combination of caspofungin and low-dose trimethoprim/sulfamethoxazole for the treatment of severe Pneumocystis jirovecii pneumonia in renal transplant recipients. Nephrology (Carlton) 2013;18:736-742.

22 Wang E, Farmakiotis D, Yang D, McCue DA, Kantarjian HM, Kontoyiannis DP, Mathisen MS: The everevolving landscape of candidaemia in patients with acute leukaemia: non-susceptibility to caspofungin and multidrug resistance are associated with increased mortality. J Antimicrob Chemother 2015;70:2362-2368.

23 Wang JF, Xue Y, Zhu XB, Fan H: Efficacy and safety of echinocandins versus triazoles for the prophylaxis and treatment of fungal infections: a meta-analysis of RCTs. Eur J Clin Microbiol Infect Dis 2015;34:651-659.

24 Zaragoza R, Ferrer R, Maseda E, Llinares P, Rodriguez A, Epico Project G: EPICO 2.0 PROJECT. Development of educational therapeutic recommendations using the DELPHI technique on invasive candidiasis in critically ill adult patients in special situations. Rev Esp Quimioter 2014;27:196-212.

25 Zaragoza R, Ferrer R, Maseda E, Llinares P, Rodriguez A, Group EP: EPICO 2.0 project. Development of educational therapeutic recommendations using the DELPHI technique on invasive candidiasis in critically ill adult patients in special situations. Rev Iberoam Micol 2014;31:157-175.

26 Zhang C, Cheng J, Jiang Y, Liu J: Application of caspofungin in China compared with amphotericin B and fluconazole. Ther Clin Risk Manag 2014;10:737-741. 


\section{Cellular Physiology Cell Physiol Biochem 2016;39:939-949

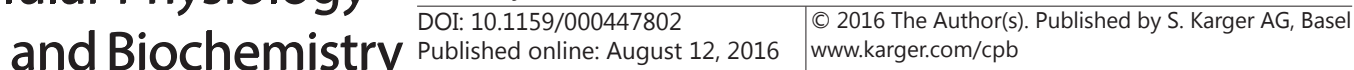 \\ Peter/Bissinger/Lang: Caspofungin-Induced Eryptosis}

27 Zhang J, Gong Y, Wang K, Kong J, Chen Y: Caspofungin versus liposomal amphotericin B for treatment of invasive fungal infections or febrile neutropenia. Chin Med J (Engl) 2014;127:753-757.

28 Hao B, Cheng S, Clancy CJ, Nguyen MH: Caspofungin kills Candida albicans by causing both cellular apoptosis and necrosis. Antimicrob Agents Chemother 2013;57:326-332.

29 Stover KR, King ST, Cleary JD: Cardiac toxicity of the echinocandins: chance or cause and effect association? J Clin Pharm Ther 2014;39:1-3.

30 Lang E, Lang F: Mechanisms and pathophysiological significance of eryptosis, the suicidal erythrocyte death. Semin Cell Dev Biol 2015;39:35-42.

31 Lang PA, Kaiser S, Myssina S, Wieder T, Lang F, Huber SM: Role of Ca2+-activated K+ channels in human erythrocyte apoptosis. Am J Physiol Cell Physiol 2003;285:C1553-C1560.

32 Alzoubi K, Calabròa S, Bissinger R, Abed M, Faggio C, Lang F: Stimulation of Suicidal Erythrocyte Death by Artesunate. Cell Physiol Biochem 2014;34:2232-2244.

33 Alzoubi K, Egler J, Abed M, Lang F: Enhanced Eryptosis Following Auranofin Exposure. Cell Physiol Biochem 2015;37:1018-1028.

34 Arnold M, Bissinger R, Lang F: Mitoxantrone-induced suicidal erythrocyte death. Cell Physiol Biochem 2014;34:1756-1767.

35 Arnold M, Lang E, Modicano P, Bissinger R, Faggio C, Abed M, Lang F: Effect of nitazoxanide on erythrocytes. Basic Clin Pharmacol Toxicol 2014;114:421-426.

36 Bissinger R, Barking S, Alzoubi K, Liu G, Liu G, Lang F: Stimulation of Suicidal Erythrocyte Death by the Antimalarial Drug Mefloquine. Cell Physiol Biochem 2015;36:1395-1405.

37 Bissinger R, Bouguerra G, Stockinger K, Abbes S, Lang F: Triggering of Suicidal Erythrocyte Death by Topotecan. Cell Physiol Biochem 2015;37:1607-1618.

38 Bissinger R, Fischer S, Jilani K, Lang F: Stimulation of Erythrocyte Death by Phloretin. Cell Physiol Biochem 2014;34:2256-2265.

39 Bissinger R, Lupescu A, Zelenak C, Jilani K, Lang F: Stimulation of eryptosis by cryptotanshinone. Cell Physiol Biochem 2014;34:432-442.

40 Bouguerra G, Aljanadi O, Bissinger R, Abbes S, Lang F: Embelin-Induced Phosphatidylserine Translocation in the Erythrocyte Cell Membrane. Cell Physiol Biochem 2015;37:1629-1640.

41 Bouguerra G, Bissinger R, Abbes S, Lang F: Stimulation of Eryptosis by Narasin. Cell Physiol Biochem 2015;37:1807-1816.

42 Bouguerra G, Bissinger R, Abbes S, Lang F: Zopolrestat Induced Suicidal Death of Human Erythrocytes. Cell Physiol Biochem 2015;37:1537-1546.

43 Briglia M, Fazio A, Faggio C, Laufer S, Alzoubi K, Lang F: Triggering of Suicidal Erythrocyte Death by Ruxolitinib. Cell Physiol Biochem 2015;37:768-778.

44 Briglia M, Fazio A, Signoretto E, Faggio C, Lang F: Edelfosine Induced Suicidal Death of Human Erythrocytes. Cell Physiol Biochem 2015;37:2221-2230.

45 Calabro S, Alzoubi K, Faggio C, Laufer S, Lang F: Triggering of Suicidal Erythrocyte Death Following Boswellic Acid Exposure. Cell Physiol Biochem 2015;37:131-142.

46 Egler J, Lang F: Licochalcone A Induced Suicidal Death of Human Erythrocytes. Cell Physiol Biochem 2015;37:2060-2070.

47 Faggio C, Alzoubi K, Calabro S, Lang F: Stimulation of suicidal erythrocyte death by PRIMA-1. Cell Physiol Biochem 2015;35:529-540.

48 Fazio A, Briglia M, Faggio C, Alzoubi K, Lang F: Stimulation of Suicidal Erythrocyte Death by Garcinol. Cell Physiol Biochem 2015;37:805-815.

49 Jacobi J, Lang E, Bissinger R, Frauenfeld L, Modicano P, Faggio C, Abed M, Lang F: Stimulation of erythrocyte cell membrane scrambling by mitotane. Cell Physiol Biochem 2014;33:1516-1526.

50 Lang E, Jilani K, Bissinger R, Rexhepaj R, Zelenak C, Lupescu A, Lang F, Qadri SM: Vitamin D-Rich Diet in Mice Modulates Erythrocyte Survival. Kidney Blood Press Res 2015;40:403-412.

51 Lang E, Zelenak C, Eberhard M, Bissinger R, Rotte A, Ghashghaeinia M, Lupescu A, Lang F, Qadri SM: Impact of Cyclin-Dependent Kinase CDK4 Inhibition on Eryptosis. Cell Physiol Biochem 2015;37:1178-1186.

52 Lupescu A, Bissinger R, Goebel T, Salker MS, Alzoubi K, Liu G, Chirigiu L, Mack AF, Qadri SM, Lang F: Enhanced suicidal erythrocyte death contributing to anemia in the elderly. Cell Physiol Biochem 2015;36:773-783.

53 Lupescu A, Bissinger R, Herrmann T, Oswald G, Jilani K, Lang F: Induction of suicidal erythrocyte death by novobiocin. Cell Physiol Biochem 2014;33:670-680.

54 Lupescu A, Bissinger R, Warsi J, Jilani K, Lang F: Stimulation of erythrocyte cell membrane scrambling by gedunin. Cell Physiol Biochem 2014;33:1838-1848. 


\section{Cellular Physiology Cell Physiol Biochem 2016;39:939-949

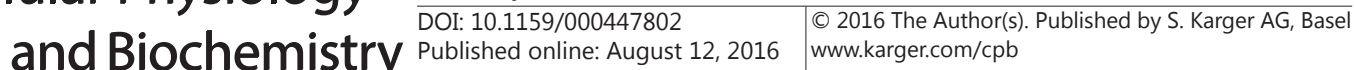 \\ Peter/Bissinger/Lang: Caspofungin-Induced Eryptosis}

55 Malik A, Bissinger R, Calabro S, Faggio C, Jilani K, Lang F: Aristolochic Acid Induced Suicidal Erythrocyte Death. Kidney Blood Press Res 2014;39:408-419.

56 Officioso A, Alzoubi K, Manna C, Lang F: Clofazimine Induced Suicidal Death of Human Erythrocytes. Cell Physiol Biochem 2015;37:331-341.

57 Oswald G, Alzoubi K, Abed M, Lang F: Stimulation of suicidal erythrocyte death by ribavirin. Basic Clin Pharmacol Toxicol 2014;114:311-317.

58 Peter T, Bissinger R, Enkel S, Alzoubi K, Oswald G, Lang F: Programmed erythrocyte death following in vitro Treosulfan treatment. Cell Physiol Biochem 2015;35:1372-1380.

59 Stockinger K, Bissinger R, Bouguerra G, Abbes S, Lang F: Enhanced Eryptosis Following Exposure to Carnosic Acid. Cell Physiol Biochem 2015;37:1779-1791.

60 Tesoriere L, Attanzio A, Allegra M, Cilla A, Gentile C, Livrea MA: Oxysterol mixture in hypercholesterolemiarelevant proportion causes oxidative stress-dependent eryptosis. Cell Physiol Biochem 2014;34:10751089.

61 Waibel S, Bissinger R, Bouguerra G, Abbes S, Lang F: Saquinavir Induced Suicidal Death of Human Erythrocytes. Cell Physiol Biochem 2015;37:1973-1982.

62 Zierle J, Bissinger R, Egler J, Lang F: Lapatinib Induced Suicidal Death of Human Erythrocytes. Cell Physiol Biochem 2015;37:2275-2287.

63 Bissinger R, Bouguerra G, Al Mamun Bhuyan A, Waibel S, Abbes S, Lang F: Efavirenz Induced Suicidal Death of Human Erythrocytes. Cell Physiol Biochem 2015;37:2496-2507.

64 Bissinger R, Waibel S, Bouguerra G, Al Mamun Bhuyan A, Abbes S, Lang F: Enhanced Eryptosis Following Exposure to Lopinavir. Cell Physiol Biochem 2015;37:2486-2495.

65 Briglia M, Calabro S, Signoretto E, Alzoubi K, Laufer S, Faggio C, Lang F: Fucoxanthin Induced Suicidal Death of Human Erythrocytes. Cell Physiol Biochem 2015;37:2464-2475.

66 Briglia M, Fazio A, Faggio C, Lang F: Triggering of Suicidal Erythrocyte Death by Zosuquidar. Cell Physiol Biochem 2015;37:2355-2365.

67 Fazio A, Briglia M, Faggio C, Alzoubi K, Lang F: Oxaliplatin Induced Suicidal Death of Human Erythrocytes. Cell Physiol Biochem 2015;37:2393-2404.

68 Macczak A, Cyrkler M, Bukowska B, Michalowicz J: Eryptosis-inducing activity of bisphenol A and its analogs in human red blood cells (in vitro study). J Hazard Mater 2016;307:328-335.

69 Officioso A, Alzoubi K, Lang F, Manna C: Hydroxytyrosol inhibits phosphatidylserine exposure and suicidal death induced by mercury in human erythrocytes: Possible involvement of the glutathione pathway. Food Chem Toxicol 2016;89:47-53.

70 Officioso A, Manna C, Alzoubi K, Lang F: Bromfenvinphos induced suicidal death of human erythrocytes. Pestic Biochem Physiol 2016;126:58-63.

71 Qadri SM, Donkor DA, Bhakta V, Eltringham-Smith LJ, Dwivedi DJ, Moore JC, Pepler L, Ivetic N, Nazi I, Fox-Robichaud AE, Liaw PC, Sheffield WP: Phosphatidylserine externalization and procoagulant activation of erythrocytes induced by Pseudomonas aeruginosa virulence factor pyocyanin. J Cell Mol Med 2016;10.1111/jcmm.12778

72 Zierle J, Bissinger R, Bouguerra G, Abbes S, Lang F: Triggering of Suicidal Erythrocyte Death by Regorafenib. Cell Physiol Biochem 2016;38:160-172.

73 Pagano M, Faggio C: The use of erythrocyte fragility to assess xenobiotic cytotoxicity. Cell Biochem Funct 2015;33:351-355.

74 Alzoubi K, Calabro S, Faggio C, Lang F: Stimulation of suicidal erythrocyte death by sulforaphane. Basic Clin Pharmacol Toxicol 2015;116:229-235.

75 Signoretto E, Honisch S, Briglia M, Faggio C, Castagna M, Lang F: Nocodazole Induced Suicidal Death of Human Erythrocytes. Cell Physiol Biochem 2016;38:379-392.

76 Abed M, Towhid ST, Mia S, Pakladok T, Alesutan I, Borst O, Gawaz M, Gulbins E, Lang F: Sphingomyelinaseinduced adhesion of eryptotic erythrocytes to endothelial cells. Am J Physiol Cell Physiol 2012;303:C991999.

77 Lau IP, Chen H, Wang J, Ong HC, Leung KC, Ho HP, Kong SK: In vitro effect of CTAB- and PEG-coated gold nanorods on the induction of eryptosis/erythroptosis in human erythrocytes. Nanotoxicology 2012;6:847856.

78 Maellaro E, Leoncini S, Moretti D, Del Bello B, Tanganelli I, De Felice C, Ciccoli L: Erythrocyte caspase-3 activation and oxidative imbalance in erythrocytes and in plasma of type 2 diabetic patients. Acta Diabetol 2013;50:489-495. 


\section{Cellular Physiology Cell Physiol Biochem 2016;39:939-949

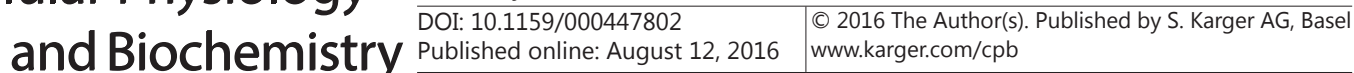 \\ Peter/Bissinger/Lang: Caspofungin-Induced Eryptosis}

79 Wurthwein G, Cornely OA, Trame MN, Vehreschild JJ, Vehreschild MJ, Farowski F, Muller C, Boos J, Hempel G, Hallek M, Groll AH: Population pharmacokinetics of escalating doses of caspofungin in a phase II study of patients with invasive aspergillosis. Antimicrob Agents Chemother 2013;57:1664-1671.

80 Abed M, Feger M, Alzoubi K, Pakladok T, Frauenfeld L, Geiger C, Towhid ST, Lang F: Sensitization of erythrocytes to suicidal erythrocyte death following water deprivation. Kidney Blood Press Res 2013;37:567-578.

81 Voelkl J, Alzoubi K, Mamar AK, Ahmed MS, Abed M, Lang F: Stimulation of suicidal erythrocyte death by increased extracellular phosphate concentrations. Kidney Blood Press Res 2013;38:42-51.

82 Abed M, Artunc F, Alzoubi K, Honisch S, Baumann D, Foller M, Lang F: Suicidal erythrocyte death in endstage renal disease. J Mol Med (Berl) 2014;92:871-879.

83 Ahmed MS, Langer H, Abed M, Voelkl J, Lang F: The uremic toxin acrolein promotes suicidal erythrocyte death. Kidney Blood Press Res 2013;37:158-167.

84 Polak-Jonkisz D, Purzyc L: Ca(2+) influx versus efflux during eryptosis in uremic erythrocytes. Blood Purif 2012;34:209-210; author reply 210.

85 Calderon-Salinas JV, Munoz-Reyes EG, Guerrero-Romero JF, Rodriguez-Moran M, Bracho-Riquelme RL, Carrera-Gracia MA, Quintanar-Escorza MA: Eryptosis and oxidative damage in type 2 diabetic mellitus patients with chronic kidney disease. Mol Cell Biochem 2011;357:171-179.

86 Lang PA, Beringer O, Nicolay JP, Amon O, Kempe DS, Hermle T, Attanasio P, Akel A, Schafer R, Friedrich B, Risler T, Baur M, Olbricht CJ, Zimmerhackl LB, Zipfel PF, Wieder T, Lang F: Suicidal death of erythrocytes in recurrent hemolytic uremic syndrome. J Mol Med (Berl) 2006;84:378-388.

87 Nicolay JP, Schneider J, Niemoeller OM, Artunc F, Portero-Otin M, Haik G, Jr., Thornalley PJ, Schleicher E, Wieder T, Lang F: Stimulation of suicidal erythrocyte death by methylglyoxal. Cell Physiol Biochem 2006;18:223-232.

88 Lang E, Gatidis S, Freise NF, Bock H, Kubitz R, Lauermann C, Orth HM, Klindt C, Schuier M, Keitel V, Reich M, Liu G, Schmidt S, Xu HC, Qadri SM, Herebian D, Pandyra AA, Mayatepek E, Gulbins E, Lang F, Haussinger D, Lang KS, Foller M, Lang PA: Conjugated bilirubin triggers anemia by inducing erythrocyte death. Hepatology 2015;61:275-284.

89 Kempe DS, Akel A, Lang PA, Hermle T, Biswas R, Muresanu J, Friedrich B, Dreischer P, Wolz C, Schumacher U, Peschel A, Gotz F, Doring G, Wieder T, Gulbins E, Lang F: Suicidal erythrocyte death in sepsis. J Mol Med (Berl) 2007;85:273-281.

90 Lang PA, Schenck M, Nicolay JP, Becker JU, Kempe DS, Lupescu A, Koka S, Eisele K, Klarl BA, Rubben H, Schmid KW, Mann K, Hildenbrand S, Hefter H, Huber SM, Wieder T, Erhardt A, Haussinger D, Gulbins E, Lang F: Liver cell death and anemia in Wilson disease involve acid sphingomyelinase and ceramide. Nat Med 2007;13:164-170.

91 Harrison HE, Bunting H, Ordway NK, Albrink WS: The Pathogenesis of the Renal Injury Produced in the Dog by Hemoglobin or Methemoglobin. J Exp Med 1947;86:339-356.

92 Borst O, Abed M, Alesutan I, Towhid ST, Qadri SM, Foller M, Gawaz M, Lang F: Dynamic adhesion of eryptotic erythrocytes to endothelial cells via CXCL16/SR-PSOX. Am J Physiol Cell Physiol 2012;302:C644-C651.

93 Silva-Herdade AS, Andolina G, Faggio C, Calado A, Saldanha C: Erythrocyte deformability - A partner of the inflammatory response. Microvasc Res 2016;107:34-38.

94 Andrews DA, Low PS: Role of red blood cells in thrombosis. Curr Opin Hematol 1999;6:76-82.

95 Chung SM, Bae ON, Lim KM, Noh JY, Lee MY, Jung YS, Chung JH: Lysophosphatidic acid induces thrombogenic activity through phosphatidylserine exposure and procoagulant microvesicle generation in human erythrocytes. Arterioscler Thromb Vasc Biol 2007;27:414-421.

96 Zwaal RF, Comfurius P, Bevers EM: Surface exposure of phosphatidylserine in pathological cells. Cell Mol Life Sci 2005;62:971-988.

97 Closse C, Dachary-Prigent J, Boisseau MR: Phosphatidylserine-related adhesion of human erythrocytes to vascular endothelium. Br J Haematol 1999;107:300-302.

98 Gallagher PG, Chang SH, Rettig MP, Neely JE, Hillery CA, Smith BD, Low PS: Altered erythrocyte endothelial adherence and membrane phospholipid asymmetry in hereditary hydrocytosis. Blood 2003;101:46254627.

99 Pandolfi A, Di Pietro N, Sirolli V, Giardinelli A, Di Silvestre S, Amoroso L, Di Tomo P, Capani F, Consoli A, Bonomini M: Mechanisms of uremic erythrocyte-induced adhesion of human monocytes to cultured endothelial cells. J Cell Physiol 2007;213:699-709.

100 Wood BL, Gibson DF, Tait JF: Increased erythrocyte phosphatidylserine exposure in sickle cell disease: flowcytometric measurement and clinical associations. Blood 1996;88:1873-1880. 